2018-08-30

Sweden shows how the Nordic model could improve women's wellbeing and create a better society

Evans, $\mathrm{H}$

http://hdl.handle.net/10026.1/15973

10.1136/bmj.k3629

BMJ

BMJ

All content in PEARL is protected by copyright law. Author manuscripts are made available in accordance with publisher policies. Please cite only the published version using the details provided on the item record or document. In the absence of an open licence (e.g. Creative Commons), permissions for further reuse of content should be sought from the publisher or author. 


\title{
Sweden shows how the Nordic model could improve women's wellbeing and create a better society
}

\author{
Harriet Evans survivor and activist ${ }^{1}$, Richard Byng general practitioner and ${ }^{2}$ professor in primary \\ care research $^{2}$, Lynne Callaghan senior research fellow ${ }^{2}$, Anna Fisher chair ${ }^{1}$
}

${ }^{1}$ Nordic Model Now! London SW17 8BY, UK; ${ }^{2}$ Community and Primary Care Research Group, Clinical Trials and Population Studies, University of Plymouth Faculty of Medicine and Dentistry, Room N14, ITTC Building, Plymouth Science Park, Plymouth PL6 8BX, UK

Proponents of the two main opposing models of legislating sex work (full decriminalisation versus the Nordic model) agree that criminalising sellers of sex is counterproductive, but the overall aims of and evidence for the two models were not fully explored by Howard. ${ }^{1}$ Our experience is that distress, trauma, substance misuse, poverty, or coercion can lead to prostitution, causing further emotional and physical harm. ${ }^{2}$

Harriet, survivor and activist, says: "My life is a catalogue of shame: sexual abuse as a child; chronic mental illness; homelessness; prostitution. Each layer of shame has augmented my sense of worthlessness. I was forced into prostitution by my ill health, a broken benefits system, and threats of eviction. Under full decriminalisation, this pathway would be endorsed by the state."

The Nordic model is a socially progressive movement, which sees prostitution as harmful to the public good and requires men to stop buying sex. Legislation to reduce demand and social programmes to support exit protect the most vulnerable. Conversely, full decriminalisation normalises prostitution as "work."

Harriet: "Abel's commentary ${ }^{3}$ boasts that decriminalisation enables prostitutes to contact the police when an assault occurs. This is not what a safe workplace looks like. I knew that I could have been murdered; I couldn't fight back when the clients raped me. Full decriminalisation colludes with the notion that a woman's consent is negotiable; it can be bought; it can be ignored."
Sweden provides a case study of the Nordic model, reporting reductions in street prostitution and no overall rise compared with comparators ${ }^{4}$; reductions in demand from $\mathrm{men}^{4}$; and support of the police. ${ }^{5}$ By contrast, claims for health benefits of the New Zealand decriminalisation model are not based on measured outcomes. ${ }^{13}$ Claims of consensus of support from health workers are inaccurate; in 2017 the BMA's annual representative meeting voted decisively against it. ${ }^{6}$ We support the Nordic model based on the evidence we have; further research is needed to understand how best to make and monitor progress elsewhere.

Competing interests: None declared.

Full response at: https://www.bmj.com/content/361/bmj.k2609/rr-0.

Howard S. Better health for sex workers: which legal model causes least harm?BM 2018;361:k2609. 10.1136/bmj.k2609 29925573

2 Nordic Model Now! Harriet's story. https://nordicmodelnow.org/2018/06/12/metoo-storiesof-the-sex-trade-2/

3 Abel G. Commentary: Sex work is here to stay and decriminalisation improves safety and social justice. BMJ 2018:361'k2687. 10.1136/bmj.k2687 29925628

4 Government Offices of Sweden. Evaluation of the prohibition of the purchase of sexual services. https://www.government.se/articles/2011/03/evaluation-of-the-prohibition-of-thepurchase-of-sexual-services/

5 Nordic Model Now! How the Swedish Sex Purchase Law moved the shame of prostitution from the women to the punters. https://nordicmodelnow.org/2018/07/20/how-the-swedishsex-purchase-law-moved-the-shame-of-prostitution-from-the-women-to-the-punters/

6 British Medical Association. British Medical Association minutes of 2017 annual representative meeting. https://www.bma.org.uk/-/media/files/pdfs/about $\% 20$ the $\% 20 \mathrm{bma}$ how\%20we\%20work/arm\%202017/arm-2017-minutes-unconfirmed.pdt?la=en (p22)

Published by the BMJ Publishing Group Limited. For permission to use (where not already granted under a licence) please go to http://group.bmj.com/group/rights-licensing/ permissions 